\title{
DEVELOPMENT OF PALM TRUNK INJECTOR FOR CONTROLLING RED PALM WEEVIL
}

\author{
Eliwa,A. A.
}

\begin{abstract}
The present research aimed essentially to optimize the performance of trunk injection device suitable for controlling red palm weevil (Rhynchophorus Ferrugineus), which represents the most economically important insect pest of date palm trees in Egypt. Field trials were conducted in Sharkia and Ismaillia Governorates to determine some operating parameters influencing the performance of developed device under different factors. The lost insecticide, device productivity torque and energy requirements, recovery percentage or controlling efficiency and operation cost were calculated.
\end{abstract}

Results indicated that the lowest values of lost insecticide were (0.0, 1.10 and $1.3 \%$ ) with manual injection method when using boring bar with two nozzles, while the highest value of lost insecticide (9.7\%) happened when using boring bar with 5 nozzles and electric drill. The highest device productivity of $7.5 \mathrm{palm} / \mathrm{h}$ was when using electric drill at infestation palm having diameter $\leq 25 \mathrm{~cm}$. Meanwhile, the lowest productivity of 3.0 palm/h was by manual method using fixed boring bar at high palm diameter $\geq 40$. The torque required to rotate the boring bar inside palm trunk increased with increasing date palm age or diameter and when increasing the pitch from 3 to $6 \mathrm{~mm}$. Maximum value of energy 0.18, 0.22 and $0.25 \mathrm{~kW} . \mathrm{h} / \mathrm{palm}$ was recorded at manual fixed boring bar under all diameters $\leq 25,25-40$ and $\geq 40 \mathrm{~cm}$ respectively., Meanwhile, minimum value $0.10 \mathrm{~kW} . \mathrm{h} /$ palm was found when using electric drill at $\leq 25 \mathrm{~cm}$ diameter. The recovery percentage increased when using movable boring bar comparing to electric method by 44.4, 37.4 and 30.1\%. The controlling cost was $12.05 \mathrm{LE} /$ palm, while $13.75 \mathrm{LE} /$ palm in manual and electric methods respectively, in addition to providing an electricity source.

Key words: Manual and electric injection device, red palm weevil, date palm, recovery percentage.

* Senior Res., Ag. Eng. Res. Inst.(AEnRI), Dokki; Giza, Egypt. 


\section{INTRODUCTION}

ed palm weevil was introduced to Egypt since 1992, through a
gift from some Arabian country. Due to insufficient information
and unexpected pest entry, problem was started since that date. Number of infested locations tell 2000, covers all 26 Egyptian governorates through 2007(EL-Sebay 2007). The insect has spread into Egypt (Shamseldeen and Abd-Elgawad, 1994), Bangladesh, Solomon Islands and Iran (Faghih, 1996), Spain (Barranco et al., 1996) Israel and Jordan 1999 (Sorker et al., 2004). Abd EL-Mageed (2007) reported that red palm weevil infestation lead to decreasing of $93 \%$ from date palm crop).

EL-Rabee (2004) developed a local hydraulic device for date palm trunk injection. The device consists of hydraulic drill, hydraulic injection pump and insecticide tank. The hydraulic motion is achieved by means of hydraulic oil pump of Ferguson $35 \mathrm{hp}$ tractor through hose connection. Hernandez et al. (2003) reported that field experiments were conducted in southern Spain to determine the effect of 9 insecticides and different application methods ( soil application, trunk injection , sprays and combination of trunk injection and sprays) to control red palm weevil. The highest mortality was obtained with the combination of trunk injections and sprays with some insecticide.

In extensive studies on the chemical control of the red palm weevil, all stages of the pest were unaffected with the tested granular pesticides mixed with soil around the trunk of the tree.

Excellent results were recorded with Gastoxin 57\%. All stages of the pest were killed in the case of ( 3 tablets x 3 holes) per each tree. (Saleh et al., 1996)

Huang-Z (2006) reported that the control efficacy of insecticides applied through tree trunk injection and lacquer technique reached $98 \%$ and $81 \%$, respectively. The rates of population reduction were more stable when the insecticides were applied through tree trunk injection and lacquer method than when insecticides were sprayed to the foliage. Imtiaze et al. (2005) found that injections with systemic insecticides have been economically cheap, environmentally safe and comparatively effective for the control of leaf miner and sucking pests. Janakirman and Rao (2001) studied the effectiveness of different systemic insecticides against the pseudo stem 
borer. Two field experiments were conducted with banana cv. Injection of insecticides caused death of grubs and adults inside the plants.

The UAE has made extensive efforts to destroy this weevil, but so far these efforts have been unsuccessful. It is expected that about 100 thousand date palms will be lost in the next 10 years due to the RPW, (AlHammadi 2006).

Larvae bore inside the trunk in all directions and the different stages of insect are abundantly within infested trunk all year round (Batt and Girgis, 1996).

Girgis et al., (2002) compared between four trunk injection methods to remedy the infested palm trees with RPW. The differentiation between them was depended on depth, width, directions of cavities made by larvae and number of holes. A hole is made by an iron pin (40 cm long and 2.5 $\mathrm{cm}$ diam). The fourth method (7-13 substitutive holes and 15-20 cm depth) was the best for remedy of the infested palm trees and can be recommended for the control of RPW infesting in Egypt.

Soroker et al., (2004) developed a monitoring system that will identify and differentiate larval activity from among the mixture of sounds captured by the sensitive microphone attached to the palm trunk. Using a sampling frequency of $44.1 \mathrm{kH}_{\mathrm{Z}}$ the typical crunching sound was found to appear in bouts lasting each 3 to $10 \mathrm{~ms}$.

In India, the infestation of RPW is effectively controlled by chemical method; all holes in the trunk of infested palm are plugged. Then a hole just above the infested region is drilled and a suspension of insecticide is then poured into it (Kranz et al. 1978 and Nair, 1986). Another method of control is the use of phosphine with aluminum phosphide tablets (Sadakathulla, 1991).

Abd Allah and Khatri in Oman (2000 and 2005) investigated the effectiveness of trunk injection in comparison to using fumigant action of phosphine in controlling the RPW

In making a hole an electric drill with a bit of $40 \mathrm{~cm}$ long and $1.9 \mathrm{~cm}$ diam. was used. A hole $30-35 \mathrm{~cm}$ deep and inclined at an angle 30 downward from horizontal, and a plastic tube $45 \mathrm{~cm}$ long and $1.3 \mathrm{~cm}$ diam. was inserted into the hole.

The trunk injection can be used as one of the techniques for RPW controlling. Eliwa et al. (2007) study the economic and technical 
determinants for origination a specific technical workshop for fabricating RPW controlling device. As well as studying the difficulties and obstacles that distribution device hinders and how to overcome such problems. The study depended largely on methods and economic analysis to evauate achievement.

\section{The objectives of the present research are:}

1-. Developing the trunk injection device in such case to reduce controlling span time, and increasing device productivity and controlling efficiency.

2- Evaluating the developed device performance under different operating parameters.

\section{MATERIAL AND METHODS}

Field experiments were carried out at El Kassassin and El Salhia regions Ismailia and El Sharkia Governorates respectively. Some engineering parameters affecting the performance of trunk injection device were studied to overcome the problems noticed through previous experiments for controlling red palm weevil. Different insecticide doses according to palm diameter or age, using diluted chlorpyrifos $(48 \% \mathrm{EC})$ at concentration of $0.3 \%$, were applied on the infested palm with RPW, as fallows:

One or two holes were made about $15-20 \mathrm{~cm}$ depth and about $10-20 \mathrm{~cm}$ above the attack point (the place where a thick fluid oozed out of the trunk). A hole is madeby fixed or movable boring bar or by electric drill. Insecticide was poured into the hole by an injection hand pump, Fig. (1and 2). The inspection was carried out two weeks after treatment and the results were evaluated as follows : observation of the fluid oozed wherefrom opaque or limpid, acrid odor or odorless and, in some cases, partial dissection was carried out of the remedy area to see any pest stages whether alive or dead.

\section{Trunk injection device befor development}

The trunk injection device is locally made for controlling red palm weevil. It consists mainly of two parts, boring device and hydraulic injection pump.

\section{Boring device:}

The boring part consists of frame, binding chain, binding bar and boring bar with boring pit having total mass of $8 \mathrm{~kg}$ Fig, (1). The boring bar is a 
hallow shaft having $75 \mathrm{~cm}$ total length, $40 \mathrm{~cm}$ screwed length with $22 \mathrm{~mm}$ diam. and $3 \mathrm{~cm}$ screwed length $19 \mathrm{~mm}$ diam. There are five nozzles $5 \mathrm{~mm}$ to discharge insecticide.

\section{Injection pump:}

The hydraulic injection pump had insecticide tank $50 \mathrm{X} 15 \mathrm{X} 17 \mathrm{~cm}$. There is a metal carrier to carry the pump and fix it on the frame by two hooks for controlling top infestations.

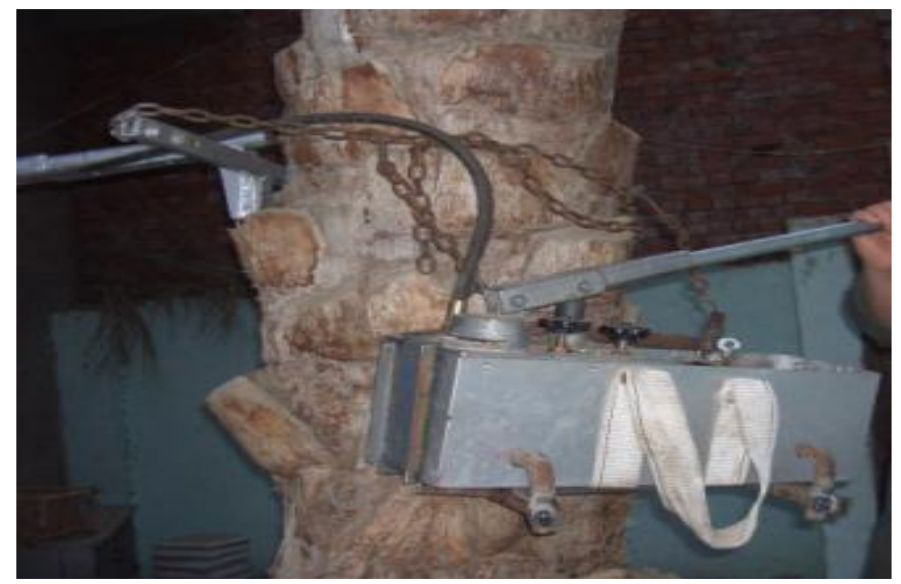

Fig. (1): The developed controlling device.

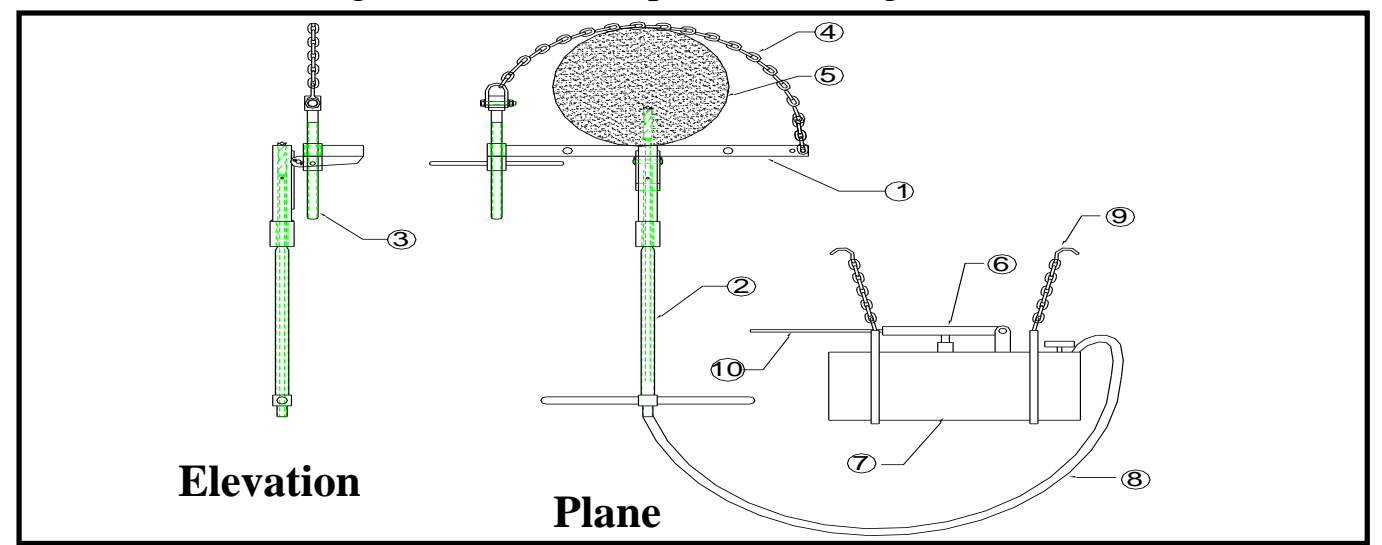

Fig. (2): The schematic diagram of controlling red palm weevil system.

\begin{tabular}{|l|l|}
\hline 1. Frame & 6.Piston pump \\
\hline 2. Boring bar with bring bit & 7.Injection insecticide pump \\
\hline 3.Binding bar & 8. Roper hose \\
\hline 4.Detachable link chain & 9. Hook \\
\hline 5.Infestation date palm & 10. Hand of the pump \\
\hline
\end{tabular}


The specifications of injection pump are as follows:

\begin{tabular}{|c|c|c|c|}
\hline Model & RP 50-60 & Weight & $8 \mathrm{~kg}$ \\
\hline Made & Germany & Druckmax & $50 \mathrm{bar} / 5 \mathrm{Mpa}$ \\
\hline Length & $50 \mathrm{~cm}$ & Temp. max & $50^{\circ} \mathrm{C}$ \\
\hline Width & $12.5 \mathrm{~cm}$ & Size & $10 \mathrm{~L}$ \\
\hline Height & $18 \mathrm{~cm}$ & & \\
\hline
\end{tabular}

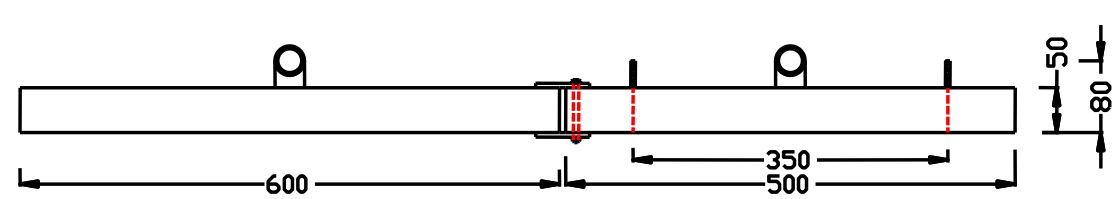

Elevation

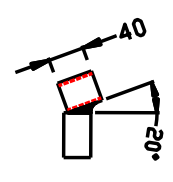

S.V.

Fig.(3) Elevation and S.V view of developed injection device fram after devolpment

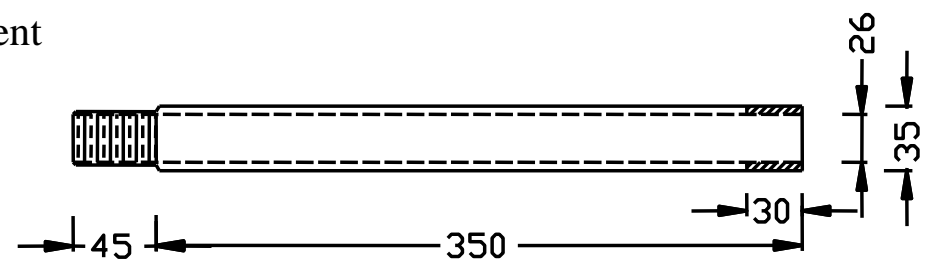

Fig. (4) Elevation view of boring bar casing.
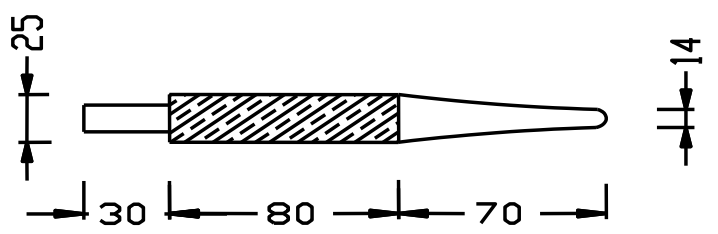

Fig.(5) Stopper to prevent insecticide loss during injection process 


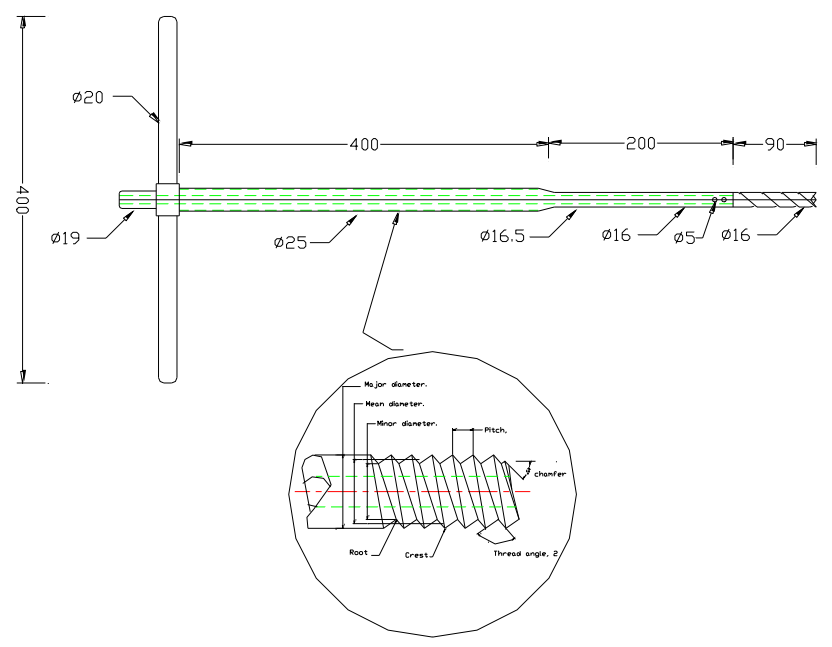

Fig. (6): The boring bar before development.
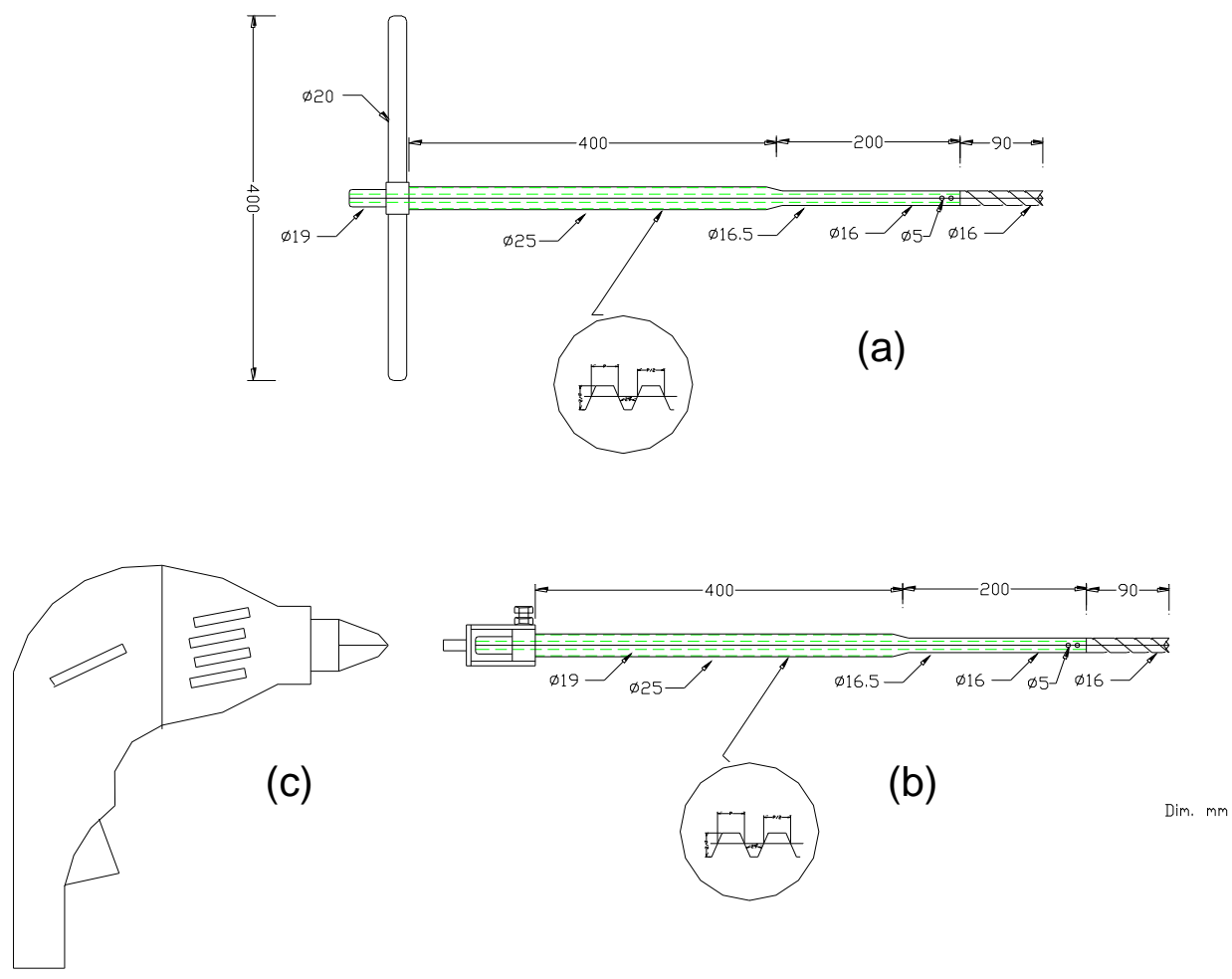

Fig. (7):a - The manual boring bar after development, b-: electric boring bar after development, and c: electric drill. 


\section{$\underline{\text { Trunk injection device after development }}$}

Such development had been introduced to overcome the problems noticed under controlling operation using the first trunk injection prototype before development.Through the privous study, there are some remarks as follows:

1- Insecticide exits on palm trunk surface during injection process and is lost.

2- The pump base represents an excessive load, with need to reduce device weight.

3- To prevent hydraulic tank vibrating during injection process and insecticide falling and affect on the labor.

4- To increase device productivity in order to maximize controlling efficiency and reduce the cost.

\section{Solving the problems of insecticide losses}

Solving this problem when increasing insecticide discharge depth is by reducing nozzles number from 5 to 2 and directing boring bar or insecticide during the injection process top, bottom, right and left constantly in all infestations except in palm top infestation, the injection at bottom and right and left far from the palm apical bud.

\section{Solving the device excessive load}

To solve this problem hydraulic pump base is connected to the tank frame by two nails in the frame.A scale ruler was fixed in insecticide tank to determine required quantity from insecticide.

\section{Solving the difficulty of manual controlling problems.}

The manual controlling method requires a major effort to make 5-7 holes in palm trunk $15-20 \mathrm{~cm}$ depth with iron nail $40 \mathrm{~cm}$ long and $22 \mathrm{~mm}$ diam. This method was developed as follows:

Due to lack of electric power in most farms, increasing the pitch in the boring bar threaded part from $3-6 \mathrm{~mm}$ decreases revolution from 166 to 83 and reduces the efforts and spent time with $40 \mathrm{~cm}$ screwed length in boring bar and thus reducing about 50\% from efforts or increasing 50\% from device productivity, Fig. (6).

Electric drill (220 volt) was used to turn the boring bar instead of hand labor from a moveable generator, Fig. (7). 


\section{Solving decreasing device productivity.}

There is a positive relation between total controlling time and device productivity. Therefore, productivity increases by decreasing controlling time. In the late infestaion, the labor injects in 2-3 points espicially in the palm having diam. $>50 \mathrm{~cm}$. This requires preparing device and mounting it on the trunk each time. Boring bar has been modified wherease labor can inject in two points without device separation from the trunk.The modification included also increasing insecticide translocation inside the trunk, meaning increase in controlling percentage,Fig. (3, 4 and5).

To realize the purpose from this study, a series of field experiments were carried out under the following conditions:

1- Different number of discharge insecticide nozzles 2 and 5 nozzles.

2- Two operating boring bar systems: manual and by electric drill.

3- Two types from boring bar of pitch 3 and $6 \mathrm{~mm}$ in the screwd length.

4- Two injection device models with movable boring bar and the second with fixed boring bar.

5- Three different infestation palm diameters $(\leq 25,25-40, \geq 40 \mathrm{~cm})$.

\section{Measurements}

\section{1- Lost insecticide, \%}

Lost insectiside was collected manually during injection process in the field for each treatment. Insecticide losses percentage was calculated as follows:-

Lost insecticide, $\%=\frac{\text { Ls }}{\text { Ts }} \times 100$

Ts

Where: $\mathrm{Ls}=$ Volume of lost insecticide, $\mathrm{cm}^{3}$

$\mathrm{Ts}=$ Volume of total injected insecticide inside the trunk, $\mathrm{cm}^{3}$

\section{Controlling spent time:}

The total controlling time can be calculated as follows:

Total time $\left(\mathrm{T}_{\mathrm{t}}\right)=t_{p}+t_{b}+t_{j}+t_{c}+t_{e}+t_{s}$

Where:

$t_{p}$ : Preparing device and mounting it on the trunk time, $\mathrm{s}$

$t_{b}$ : Boring time, $\mathrm{s}$

$t_{j}:$ Insecticide injection time, $\mathrm{s}$

$t_{c}$ : Borrer coming out time, $\mathrm{s}$ 
$t_{e}$ : Separating device from the trunk time s,

$t_{s}$ : Ascending and descending time $\mathrm{s}$.

\section{Controlling device productivity:}

After one hour, the productivity of the RPW controlling device was determined by the following equation:

Where :

$$
\mathrm{C}=\frac{60}{\mathrm{~T}_{\mathrm{t}}} \quad \text { palm } / \mathrm{h} .
$$

$\mathrm{C}=$ controlling productivity device palm $/ \mathrm{h}$.

$\mathrm{T}_{\mathrm{t}}$ : Total controlling time for one date palm, min.

\section{4-Total consumed power}

The electric injection power from a moveable generator consumed was calculated from the knowledge of electric line current strength (I) and potential difference values $(\mathrm{V})$ using the following formula:

\section{Total consumed power $(\mathbf{k W})=I V \eta \cos \theta / 1000$}

\section{Where:}

I: Line current strength in amperes.

$\mathbf{V}:$ is the Voltage ( being equal to 220volt).

$\operatorname{Cos} \theta$ : Power factor (being equal to 0.85 )

$\boldsymbol{\eta}$ : Mechanical efficiency assumed (90\%).

In the manual injection method, human energy was estimated based on the power of one labor, which was considered to about $0.746 \mathrm{~kW}$, then, the human energy is determined using the following equation according to Chancellor (1981).

$(\mathrm{kW} . \mathrm{h} / \mathrm{palm})=0.764(\mathrm{~kW}) \times$ number of laborers $/ F C_{\text {actual }} \quad(\mathrm{palm} / \mathrm{h})$.

\section{5- Controlling efficiency, \%}

The total controlling efficiency was calculated according to percentage of recovery trees, three weeks after treatment, and the results were evaluated as, casing of the infestation symptoms and, in some cases, partial dissection was carried out of the treated tree and the average mortality of all stages Ma (larva, pupa and adult) was calculated according to Saleh et al. (1996) as follows:

$$
M_{a}=\frac{D_{a}+P_{d}+L_{d}}{\left(D_{2}+D_{d}\right)+\left(P_{a}+P_{d}\right)+\left(L_{\mathrm{L}}+L_{d}\right)} \times 100
$$


Where:

$D_{a}=$ No. of alive adults $\& D_{d}=$ No. of dead adults,

$P_{a}=$ No. of alive pupa $\& P_{d}=$ No. of dead pupa,

$L_{a}=$ No. of alive larva $\& L_{d}=$ No. of dead larva.

\section{6- Controlling cost:}

Hourly cost was calculated by using fixed and variable cost method (straight-Line method), using the following equation:

Total cost (L.E /h)

Operational cost of (L.E/palm) =

\section{Productivity (palm /h)}

\section{RESULTS AND DISCUSSION}

\section{1- Effect of some different operating parameters on lost isecticide:}

Fig.(8) illustrates that lost insecticide percentage increased by operating device method and nozzles number. The lowest values of lost insecticide were $(0.0,1.10$ and $1.3 \%)$ at manual injection method when using boring bar with two nozzles at different infestation palm diameters . The highest value of lost insecticide (9.7\%) was achieved when using boring bar with 5 nozzles and electric drill. This may be due to decreasing injection depth and increasing the clearance between boring bar and palm tissue owing to vibratory motion of electric drill. Therfore, the clearance allows insecticide to go outside palm trunk, espicially under high pressure.

\section{2- Effect of some different operating parameters on recovery or control efficiency $\%$.}

Fig. (9) shows that the obvious effect of injection method and insecticide translocation between palm tissues on the recovery $\%$ of infested palm tree. The highest recovery was $93 \%$ whereas all stages of the pest were killed and casing of infestation symptoms were noticed. The lowest percentage recovery 50, 57 and $65 \%$ was recorded under different palm diameters $\leq 25,25-40, \geq 40 \mathrm{~cm}$ respictevely when using electric drill for to make a hole above infested area and injection of the insecticide. The boring bar vibration of electric drill led to increasing the clearance between boring bar and palm tissue and this lead to insecticide rebound out palm serface as losses and negative effect on insecticide translocation, 
therfore lowest recovery $\%$. Increasing recovery $\%$ was in movable boring bar comparing to fixed boring bar owing to increasing insecticide control inside palm trunk, therfore increasing insecticide distribution and spread between tissues, espicially in old palm $\geq 40 \mathrm{~cm}$.

\section{3- Effect of some different operating parameters on machine productivity}

Fig. (10) shows the effect of injection method, the mean pitch and boring bar type ( movable or fixed) on injection device productivity. The highest device productivity of $7.5 \mathrm{palm} / \mathrm{h}$ resulted using electric drill at infestation palm having diameter $\leq 25 \mathrm{~cm}$. The lowest productivity of $3.0 \mathrm{palm} / \mathrm{h}$ resulted by manual method using fixed boring bar at high palm diameter $\geq 40$. The productivity was affected by palm diameter which decreased from $4.2 \mathrm{palm} / \mathrm{h}$ at $\leq 25 \mathrm{~cm}$ to $3.0 \mathrm{palm} / \mathrm{h}$ at diam. $\geq 40 \mathrm{~cm}$ at manual method, using fixed boring bar and $3 \mathrm{~mm}$ pitch.It is obvious that the productivity increased when using movable boring bar and pitch $6 \mathrm{~mm}$. This may be due to decreasing preparing and mounting device time around the trunk and separating device from the trunk time and also, decreasing $50 \%$ from boring bar revolution.

\section{4- Effect of some different operating parameters on required energy.}

Fig.(11) illustrates the relationship between mean of pitch and different levels of date palm diameters. The effect of injection method and palm diameter on energy requirements Fig. (14) shows a remarkable drop in energy requirement $\mathrm{kW} . \mathrm{h} / \mathrm{palm}$ at electric injection method comparing to manual method under all diameters owing to total control time and device productivity. Results also show that there is a positive relationship between energy values and palm diameter. Maximum value of energy $0.18,0.22$ and $0.25 \mathrm{~kW} . \mathrm{h} / \mathrm{palm}$ was recorded at manual fixed boring bar under all diameters $\leq 25,25-40$ and $\geq 40 \mathrm{~cm}$ respectively. Minimum values $0.10 \mathrm{~kW} . \mathrm{h} / \mathrm{palm}$ were found when using electric drill at $\leq 25 \mathrm{~cm}$ diameter. 


\section{Cost analysis:}

Data of cost analysis illustrated in Tables (1and 2) show that the controlling cost in manual injection methods was $12.05 \mathrm{LE} /$ palm and decreased comparing to electricity method $12.36 \%$.In our study, the main factor is recovery percentage, the highest recovery values were 90 , 91 and $93 \%$ while the lowest values were 50, 57 and $65 \%$ in manual method using movable boring bar and electric method under different palm diameters $\leq 25,25-40$ and $\geq 40 \mathrm{~cm}$ respectively.On other hand, the cost of controlling using fixed boring bar and having $3 \mathrm{~mm}$ pitch was higher than movable boring bar and having $6 \mathrm{~mm}$ pitch under all diameters.From the privious results, it is clear that movable boring bar with $3 \mathrm{~mm}$ pitch saves insecticide and recorded higer recovery percentage.

Table (1): The calculation cost for manual and electric injection device.

\begin{tabular}{|l|c|c|}
\hline \multicolumn{1}{|c|}{ Item of cost analysis } & $\begin{array}{c}\text { Manual } \\
\text { injection device }\end{array}$ & $\begin{array}{c}\text { Electric } \\
\text { injection } \\
\text { device }\end{array}$ \\
\hline A-fixed costs: & 3500 & $\mathbf{5 0 0 0}$ \\
Equipment price L.E & 4000 & $\mathbf{4 0 0 0}$ \\
Expected life ,h & $\mathbf{1 5 \%}$ & $\mathbf{1 5 \%}$ \\
Interest rate, & $\mathbf{1 0 \%}$ & $\mathbf{1 0 \%}$ \\
Machine salvage rate, & $\mathbf{1 . 1 4}$ & $\mathbf{1 . 6 2}$ \\
Total hourly fixed cost, L.E/h. & & \\
\hline B - Variabl costs: & $\mathbf{1 0 . 9 1}$ & $\mathbf{1 2 . 1 3}$ \\
Total variable costs & & \\
\hline Total operation costs L.E/h & $\mathbf{1 2 . 0 5}$ & $\mathbf{1 3 . 7 5}$ \\
\hline
\end{tabular}


Table (2): Effect of some operation parameters on productivity and cost of controlling process.

\begin{tabular}{|c|c|c|c|c|c|c|c|}
\hline $\begin{array}{c}\text { Injection } \\
\text { methods }\end{array}$ & $\begin{array}{c}\text { Labor } \\
\text { man/ day }\end{array}$ & \multicolumn{3}{|c|}{ Productivity palm/ h } & \multicolumn{3}{|c|}{$\begin{array}{c}\text { Cost of Controlling } \\
\text { LE/ palm }\end{array}$} \\
\cline { 2 - 8 } & & $\begin{array}{c}\leq 25 \\
\mathrm{~cm}\end{array}$ & $\begin{array}{c}25-40 \\
\mathrm{~cm}\end{array}$ & $\begin{array}{c}\geq 40 \\
\mathrm{~cm}\end{array}$ & $\begin{array}{c}\leq 25 \\
\mathrm{~cm}\end{array}$ & $\begin{array}{c}25-40 \\
\mathrm{~cm}\end{array}$ & $\begin{array}{c}\geq 40 \\
\mathrm{~cm}\end{array}$ \\
\hline Pitch 3mm & 1 & 4.2 & 3.5 & 3 & 2.87 & 3.44 & 4.0 \\
\hline Pitch 6mm & 1 & 6.6 & 6 & 5 & 1.83 & 2.0 & 2.41 \\
\hline $\begin{array}{c}\text { Movable } \\
\text { boring bar }\end{array}$ & 1 & 5.4 & 5 & 4.3 & 2.23 & 2.41 & 2.8 \\
\hline $\begin{array}{c}\text { Fixed boring } \\
\text { bar }\end{array}$ & 1 & 4.2 & 3.5 & 3 & 2.87 & 3.44 & 4.0 \\
\hline Electric drill & 1 & 7.5 & 6 & 5.4 & 1.83 & 2.29 & 2.55 \\
\hline
\end{tabular}

\section{CONCLUSION}

This research was conducted to evaluate different injection methods to controlling red palm weevil. Results concluded that:

1- The lowest lost insecticide \% was recorded when using boring bar with 2 nozzles.

2- The highest device productivity was recorded under manual method using boring bar with $6 \mathrm{~mm}$ pitch and electricity method.

3-Maximum value of energy $0.18,0.22$ and $0.25 \mathrm{~kW} . \mathrm{h} / \mathrm{palm}$ was recorded at manual fixed boring bar under all diameters $\leq 25,25-40$ and $\geq 40 \mathrm{~cm}$ respectively.

4- The recovery percentage increased when using movable boring bar comparing to electric method by $44.4,37.4$ and $30.1 \%$.

5- The controlling cost was $12.05 \mathrm{LE} /$ palm while it was $13.75 \mathrm{LE} / \mathrm{palm}$ in addition to providing an electricity source.In despite of decreasing the operaton cost in electric method, but the movable boring bar with 3 mmpitch achieved the highest recovery \% comparing to other methods. 

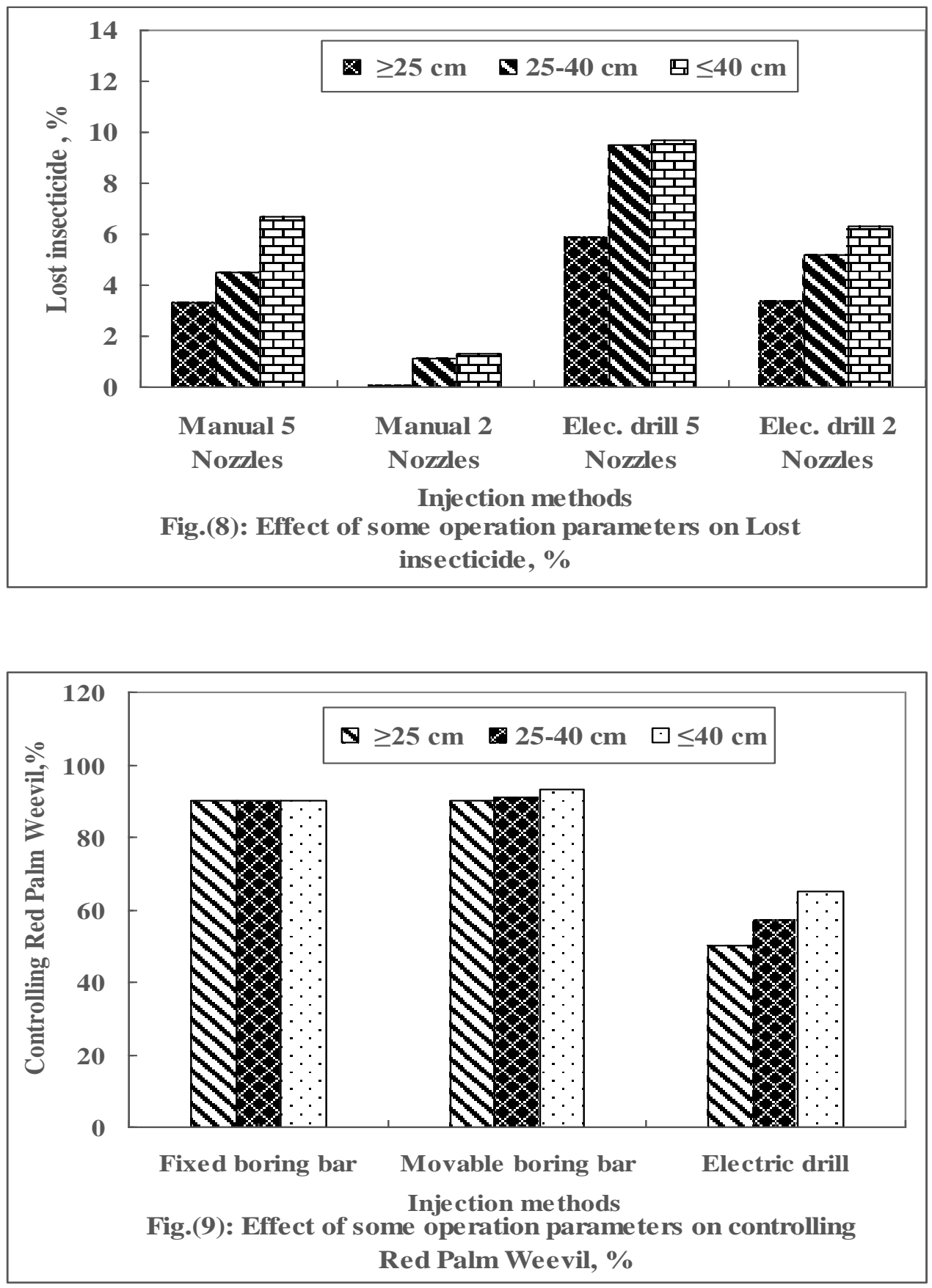

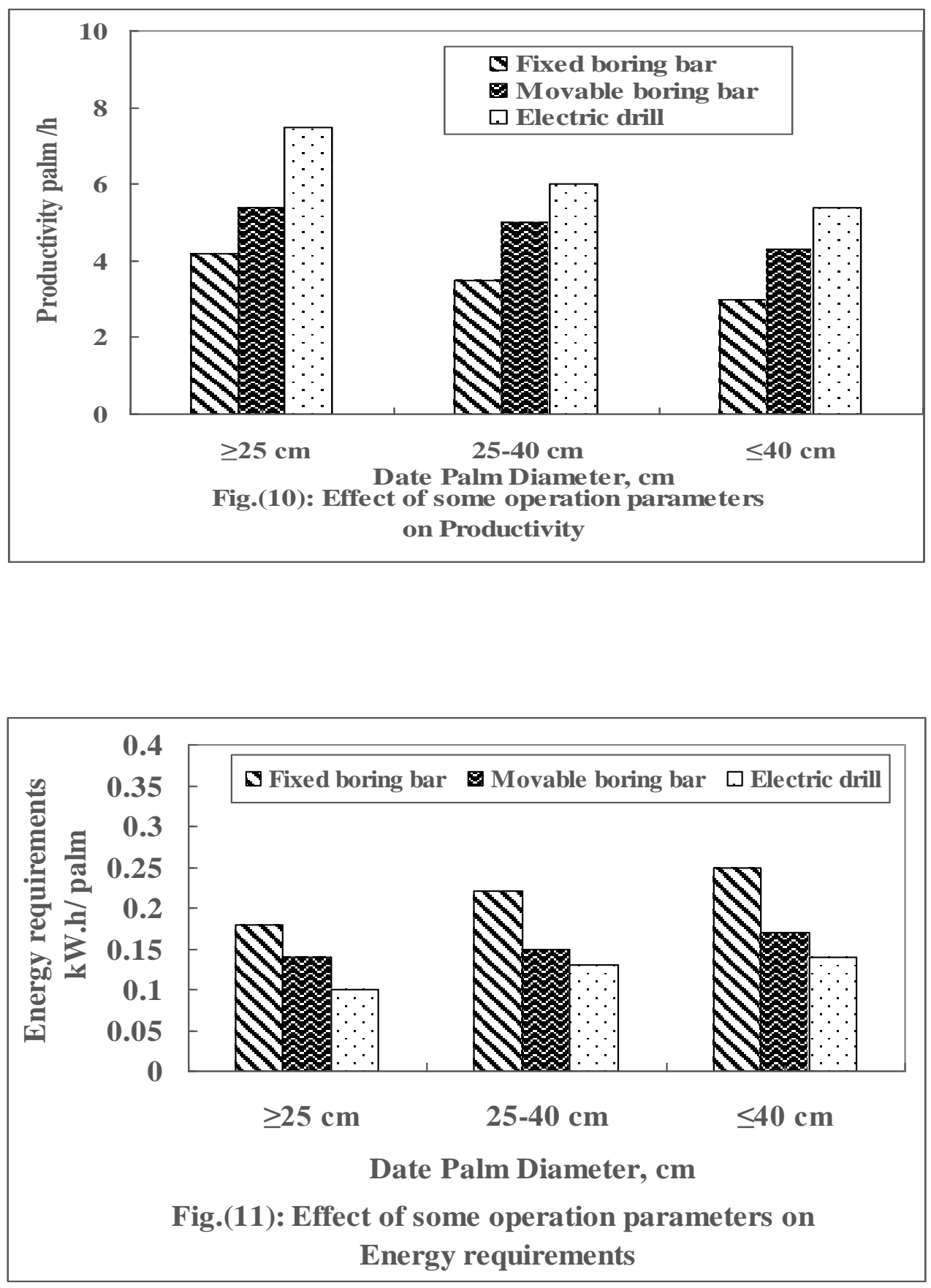

Misr. J. Ag. Eng., Jan 2012 


\section{REFERENCES}

Abdallah, F. F. and S. A. Al Khatri (2000): The effectiveness of trunk injection and fumigation for the control of the red palm weevil in date palm. J. of Plant Prot. in the Tropies 13 (1): 17-21.

Abdallah, F. F. and S. A. Al Khatri (2005): The effect of pheromone, kairomone and food bait on attracting adults of red palm weevil in the sultanate of Oman in date palm plantations. Egypt. J. Agric. Res., 83 (1): 169-177.

Abdel-Megeed, M. I. (2007) Towards a strategy for integrated management of Red Palm Weevil. Egypt.J.Agric. Rec., (1).283-312.

Al-Hammadi, M. S. (2006): Salt tolerance and current status of the date palm in the United Arab Emirates. Ph. D. Th., Grad. college , Arizona Univ., USA.

Barrancom P.; Lapena, J. D. E. and Cabella, T (1996): Red palm weevil, new pest in Europe (Coleoptra: Curculion idea). Phytoma Espara. (Feb. 1996) 7. 36-40.

Batt, A. M. and G. N. Girgis (1996): Certain studies on borers attacking date palm trees in Egypt. Menofiya J. Agric. Res., Vol. 21, No. 4 P. 9.

EL-Rabee, R. G. M. (2004) A locally hydraulic machine for insecticide injection date palm trunk. M. Sc., Th., Fac. of Agric., Bagdad Univ., 2004.

Faghih, A. A. (1996). The biology of red palm weevil phynchophorns ferruginens oliv, in saravan region (Sistan and Balnuchistan Province, Iran). Appl. Entomol. Phytopathol. 63, (in Persian).

Eliwa, A.A.; N.S. Ahmed and M.M. Abd ELAzim (2007) Evaluation of trunk injection device performance for controlling Rhynchophorus Ferrugineus and translocation of two insecticides in date palm trees, J. Biol-Chem. Environ Sci., 3(1):665-680.

EL-Sebay, Y. (2007) Studies on the infestation of Red Palm Weevil Rhynchophorus Ferrugineus. In Egypt. Egypt.J.Agric. Rec.,(1).131-162. 
Girgis, G. N.; A. M. Batt; A. M. Okil; S. M. Haggag and M. M. Abdel-Azim (2002) Evaluation of trunk injection methods for the control of red palm weevil in date palm trees in Egypt. 2nd international conf. plant protec., Res. Inst.Giza, Egypt, 21-24Dec. 2002.

Hernandez, M.D.; Folk, F.; Sanchez, A. and Fernandez-Escobar, R. (2003) Control of red palm weevil RHYNCHOPHORUS FERRUGINEUS OLV.using trunk injection and foliar sprays.Boletinde-Sanidad-Vegetal, plagas.2003;29 (4):563-573.

Huang-Zhen, YU (2006) Techniques of chemical control of Hemiberlesia pitysophila Taagi. J. OF Nanjing F. Univ. Natural Sci.Edition. 2006; 30(5):119-122.

Imtias-Ahmed; Khan, M. F. U. and Rehana-Ahmed(2005)Injection measures with systemic insecticides on fruit trees for leaf miner and sucking pests management. J. OF Experimental Zoology, India 2005; 8(1): 221-223.

Janakiraman, S. and Rao, P.V.S. (2001) Effect of injection of insecticides against banana pseudostem borer, Enttomology, TNAU, Coimbatore, 124-126, 1 (9), 2001.

Kranz, J.; H. Schmutterer and W. Kock (1987): Diseases pests and weed in tropical crops. John Wiley and Sons, N. Y. 410-412.

Morad, M.M. and A.A. Eliwa (2007): Cost analysis and energy requirements for mechanical controlling of RPW. Egypt, J. Agric. Rec, 86 (1): 43-55.

Nair, M. R. G. K. (1986): Insects and mites of crops in India. Publication and Info. Division, Indian council of Agric. Res., New Delhi: 86-87.

Sadakathulla, S. (1991): Management of red palm weevil, Rhynchophorus ferrugineus F. in coconut plantation. The planter, Kuala Lumpur, 67; 415-419.

Saleh, M. R. A.; K. A. Gouhar; A. E. Omar; A. E. Ibrahim; S. S. M. Hassanin and Kh. M. Hussein (1996): An approach to chemical 
control of the red palm weevil on the date palm in Sharkia and Ismailia Governorates, Egypt. Egypt. J. Appl. Sci., 11 (4): 250-260.

Shams El-Deen, M. M. And Abd -El-Gawad , M. M. (1994): Laboratory evaluation of six Egyptian isolates of Heteroprhabclitid nematodes for control of the red palm weevil . Egypt J. Appl. Sci. 9 : 670-679.

\section{Soroker, V.; Y. Nakache; Y. Landau; A. Mizrach; A. Hetzoni and D.} Gerling (2004): Utilization of sounding methodology to detect infestation by Rhynchophorus ferrugineus on palm offshoots. Phytoparasitica, 32 (1): 6-8.

\section{الملخص العربي \\ تطوير حاقن لجزع النخيل لمكافحة سوسة النخيل الحمراء \\ د/ عاطف عليوة}

يهدف البحث ألى تطوير جهاز لحقن النخيل وعلاج الأصابة بسوسة النخيل الحمر اء وتلافى كل الملاحظات التى تم تسجيلها أثناء التجارب العملية و الحقلية السابقة بهدف رفع كفاءة عمل الجهاز

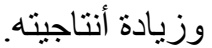

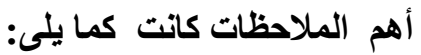
* خروج بعض المبيدات أثناء الحقن على سطح الجزع من الخئ الخارج وبخاصة فى النخيل ذات

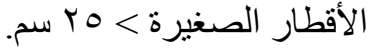
* قاعدة الطلمبة تمثل أحمال زائدة الهدف تقليل الوزن خاصة عند الحقن على أرتفاعات عالية

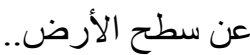
* أهتز از خز ان الطلمبة و تساقط جز ء من المبيد فى بداية الحقن مما يمثل خطورة على عامل

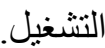
* زيادة وقت اللازم لإعداد الجهاز وتثبيته حول النخلة المصابة وأجر اء الحقن و الفك مما يقلل من

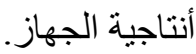
التعديلات التى تمت لحل المشكل المثلات السابقة: * تقليل عدد فتحات خروج المبيد من خمسة الى أثنين فتحة وبالتالى زيادة عمق الحقن وبعد المبيد عن السطح الخارجى للجزع.

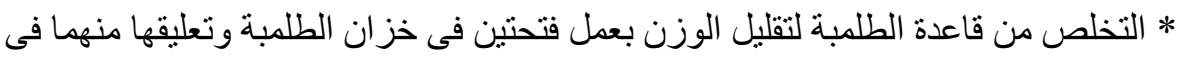

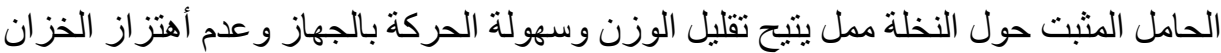
وسقوط المبيد. * لخفض الزمن الكلى لعملية الحقن وبالتالى زيادة الأنتاجية تم ذلك كما يلى:

* باحث أول بمعهل بحوث الهندسة الزراعية 
أولا: تقليل عدد دور ات المثقاب من سب ا الى 70 لفة وذلك عن طريق زيادة خطوة سن قلووظ

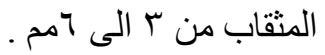
ثانيا : تطوير وضع غلاف المث المثقاب بحيث يمكن تحريكة و الحقن فى نقطتين و الجهاز مثبت حول

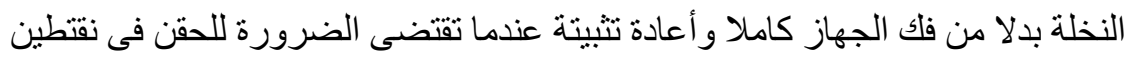

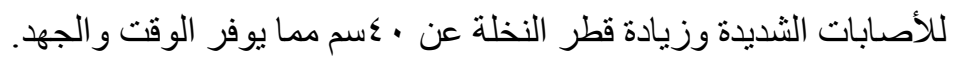

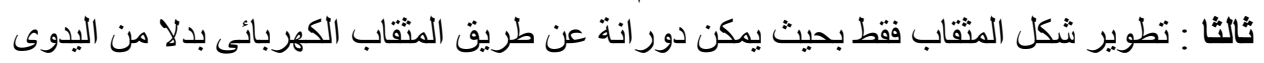
(أستخدم مولد كهربائي متنقل لإجر اء التهاء التجارب). وقد تم التوصل للنتائج التالية:-

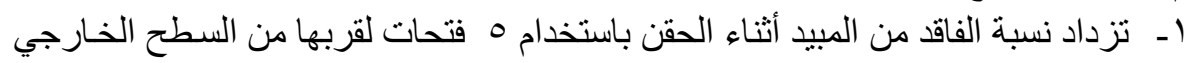

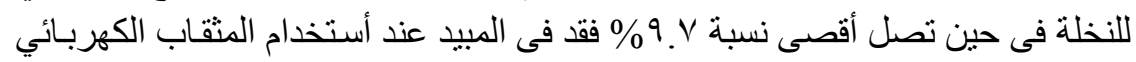

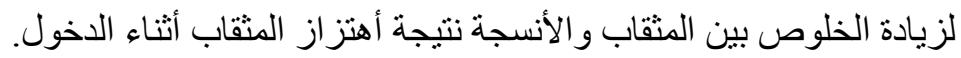

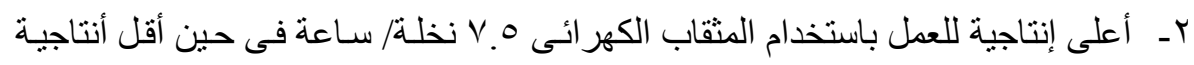

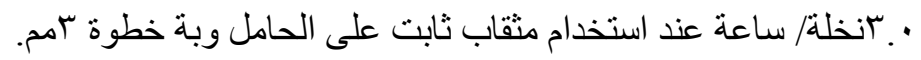

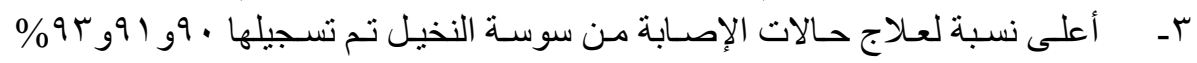

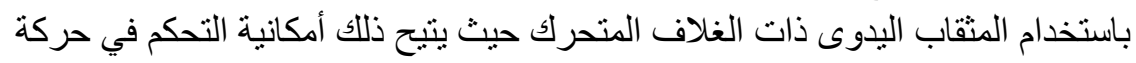

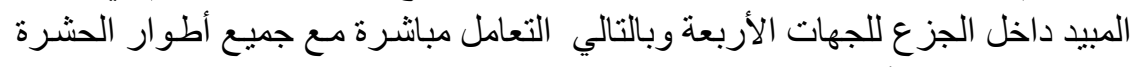

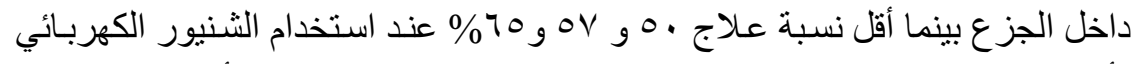

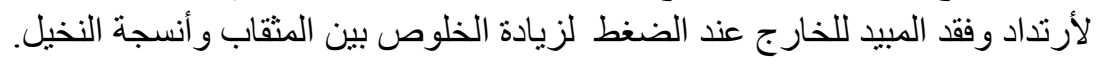

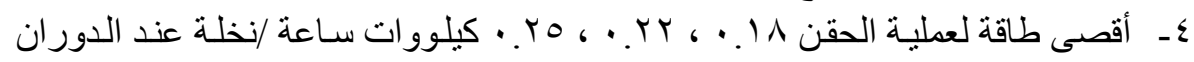

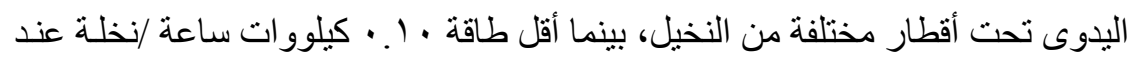

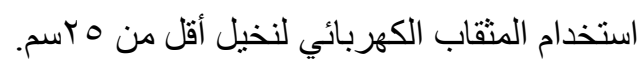

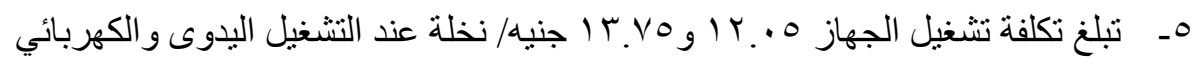

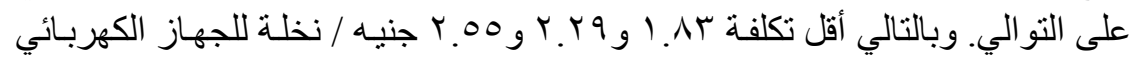

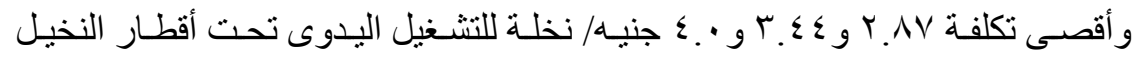

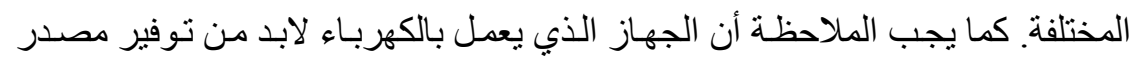

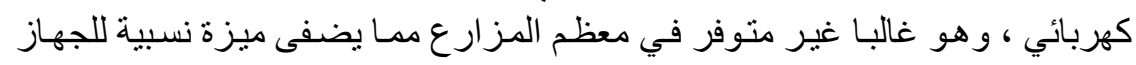

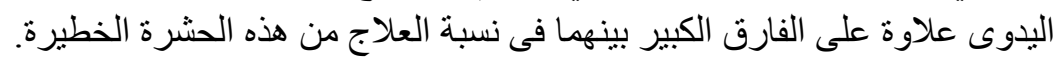

